\section{IAC Veloz: a new early-cycle black bean cultivar}

\author{
Alisson Fernando Chiorato ${ }^{1}$, João Guilherme Ribeiro \\ Gonçalves ${ }^{1}$, Daiana Alves da Silva ${ }^{{ }^{*}}$, Cássia Regina Limonta \\ Carvalho ${ }^{1}$, José Antônio de Fátima Esteves ${ }^{1}$, Luciana Larcy \\ Benchimol Reis ${ }^{1}$, Luiza Maria Bezerra Capanema ${ }^{1}$ and Sérgio \\ Augusto Morais Carbonell ${ }^{1}$
}

\begin{abstract}
The black bean cultivar IAC Veloz developed by the dry edible bean (or common bean) breeding program of the Instituto Agronômico-IAC stands out because of its early cycle, upright plant type, 1000 seed weight of 220 grams, and mean yield potential of $3770 \mathrm{~kg} \mathrm{ha}^{-1}$ in a total of 18 environments.
\end{abstract}

Keywords: Phaseolus vulgaris, early maturity, disease resistance.

\section{INTRODUCTION}

Dry edible bean, or common bean (Phaseolus vulgaris), is prominent in the Brazilian diet because of its numerous benefits to human health (Lovato et al. 2018). The seeds (commonly known as grain) with a carioca (beige with brown streaks) or black seed coat are most consumed in Brazil and preferred by consumers. They are emphasized in crop breeding programs that develop commercial common bean types.

In addition to early maturity and yield potential, plant growth habit and resistance to diseases are essential traits for releasing new cultivars in the production market. Bean seeds should also have high technological and nutritional quality. This makes the entire plant breeding process, beginning with selection of parents, an important strategy for developing cultivars (Carbonell et al. 2010, Leite et al. 2015).

Considering surveys for the 2018-2019 crop year, the area planted to black beans is $74.5 \%$ less than the area dedicated to growing common bean with colored (carioca and streaked) seed coats (CONAB 2020), influenced by regionalized consumption habits related to grain type and by the Brazilian preference for the carioca seed coat. Brazilian breeding programs have developed cultivars mainly for these two types, and this is confirmed by the equivalent yield potential of the cultivars released on the market. Still according to CONAB in 2020, the total beans production in the crop 2018-2019 was 3.02 million tons, of which 493 thousand tons are black beans, with mean yield of $1476 \mathrm{~kg} \mathrm{ha}^{-1}$.

Studies evaluate the genetic progress of common bean mainly in regard to yield of bean seeds and their components, according to Ribeiro et al. (2003) and Chiorato et al. (2010), among other authors. Barili et al. (2016) evaluated the genetic progress of black bean for approximately five decades (1960 to 2013) and observed gains for grain yield, especially after 1989, which amounted to
Crop Breeding and Applied Biotechnology 20(3): e25412034, 2020 Brazilian Society of Plant Breeding. Printed in Brazil http://dx.doi.org/10.1590/1984$70332020 v 20 n 3 c 38$ \title{
(1)
}


2.42\% annually. The authors also state that improvements occurred for other important traits, such as grain appearance, plant architecture, number of pods per plant, number of beans per pod, and 1000 seed weight.

In light of the above, the aim of this paper is to present the cultivar IAC Veloz (advanced line GEN PR 10-4-4-23) as a new alternative in black bean, which stands out in different environments by its early maturity and yield potential.

\section{GENETIC ORIGIN AND DEVELOPMENT}

Over the years, in a continual process of development of new cultivars for the production sector, the common bean breeding program of the Instituto Agronômico-IAC has made cultivars available to the market that have high yield potential, resistance to the main diseases of common bean, and marketing traits important for the product packaging industry (Carbonell et al. 2008, Carbonell et al. 2010, Chiorato et al. 2012, Carbonell et al. 2014 and Chiorato et al. 2018).

The practice of hybridization, followed by selection of superior plants, constitutes a routine activity within breeding programs for the purpose of making improved cultivars available. Thus, various hybrid combinations are obtained for selection of the one that associates a higher number of favorable traits. In this case, specifically, hybridization between two elite cultivars, one of them with a carioca seed coat (IAC Imperador) and another with a black seed coat developed by the Instituto Agronômico do Paraná - IAPAR, called IPR Tuiuiú, gave rise to the advanced line GEN PR 10-4-4/23, registered as IAC Veloz in the Ministério da Agricultura, Pecuária e Abastecimento - MAPA (Brazilian Ministry of Agriculture). The cultivar began to be developed in 2010 from hybridization between IAC Imperador (hardiness and early maturity) and IPR Tuiuiú (quality of the black bean broth and tolerance to bacterial blight), generating 18 hybrid seeds $\left(F_{1}\right)$, which were multiplied the same year to obtain the $F_{2}$ generation.

The seeds of the $\mathrm{F}_{2}$ generation were pre-germinated and transplanted in boxes containing vermiculite with sterilized substrate. Seven days after transplanting, in the laboratory, the seedlings were inoculated with three physiological races $(65,81$, and 321$)$ of anthracnose (Colletotrichum lindemunthianum). Fifteen seedlings were considered resistant to all the races inoculated, and they were individually transplanted in pots and grown in a greenhouse, being conducted by the genealogical method. In the 2010 rainy season, the 15 progenies selected were grown in the field, providing for selection within progenies of 35 plants of the $F_{2: 3}$ generation, which resulted in the opening of lines, which were once more sown in the field in the following season (winter/2011). This time, they were sown in an area with natural contamination of Fusarium oxysporum, and one plant within each one of the 35 progenies in the $F_{2: 4}$ generation was selected.

In the 2011 rainy season, the progenies selected $\left(\mathrm{F}_{2: 5}\right.$ generation), already considered lines, together with another 495 lines derived from crosses in the program, composed the competition trials. The lines derived from the cross between IAC Imperador x IPR Tuiuiú were called GEN PR 10-4-4/X, where GEN refers to the genotype; PR refers to a bean with a black seed coat; 10 refers to the year of obtaining the cross (2010); 4 refers to the hybrid combination (IAC Imperador $x$ IPR Tuiuiú); 4 refers to the plant selected in relation to resistance to anthracnose; and $X$ is in regard to the line selected from among the 35 extracted from the cross in question. After that, these 35 advanced lines were evaluated, with priority given to grain yield, early maturity, sieve yield, seed coat color, and plant height and growth habit, considering a total of four environments in the state of São Paulo: Campinas, Capão Bonito, Mococa, and Tatuí. Plants were evaluated in the three crop seasons up to the $F_{2: 8}$ generation. The advanced line number $X=23$ (GEN PR 10-4-4-23) was selected to conduct the value for cultivation and use (VCU) trials, due to the traits evaluated and the performance shown.

The VCU trials began in 2013 by the common bean breeding program of IAC, which, in addition to GEN PR10-4-4/23, included 10 other advanced lines developed by the program, with the cultivars IAC Diplomata and IAC Una used as standards controls in evaluation. The VCU trials were carried out in three crop seasons and in two crop years, following the requirements established by MAPA for setting up and conducting trials. In these trials, the line GEN PR10-4-4/23 exhibited mean yield of $2591.01 \mathrm{~kg} \mathrm{ha}^{-1}$, which was superior to the controls IAC Diplomata and IAC Una, which exhibited mean yields of $2510.04 \mathrm{~kg} \mathrm{ha}^{-1}$ and $2475.23 \mathrm{~kg} \mathrm{ha}^{-1}$, respectively. The performance shown, together with early maturity, led to recommendation of the line GEN PR10-4-4/23 to the production sector with the name of IAC Veloz because of its early 75-day cycle from emergence to physiological maturity.

\section{YIELD CAPACITY}


The mean grain yield of the cultivar IAC Veloz, compared to the two control cultivars, was higher in all three locations evaluated in the rainy crop season 2014; and in Capão Bonito at this same time, the cultivar exhibited maximum yield in relation to the other seventeen environments evaluated, at $3770.83 \mathrm{~kg} \mathrm{ha}^{-1}$. The cultivar IAC Veloz exceeded the mean yield of the two controls in $67 \%$ of the environments evaluated (Table 1 ).

This yield superiority of the cultivar IAC Veloz was observed for the combined environments, considering each crop season, with the exception of the winter crop season, for which there was no significant difference (Table 2). The mean yield values of IAC Veloz, considering six environments per crop season, were $2724.47 \mathrm{~kg} \mathrm{ha}^{-1}, 2012.79 \mathrm{~kg}$ $\mathrm{ha}^{-1}$, and $3035.78 \mathrm{~kg} \mathrm{ha}^{-1}$ in reference to the rainy, dry, and winter crop seasons, respectively. Considering combined analysis of the environments tested in the three crop seasons of common bean in the state of São Paulo, according to agroecological zoning, the overall mean of grain yield was $2591.01 \mathrm{~kg} \mathrm{ha}^{-1}, 2510.04 \mathrm{~kg} \mathrm{ha}^{-1}$, and $2475.23 \mathrm{~kg} \mathrm{ha}^{-1}$ for the rainy, dry, and winter crop seasons, respectively (Table 2). Through the results presented, the production performance associated with resistance to different races of anthracnose and Fusarium wilt, and early maturity in regard to the crop cycle, make the cultivar IAC Veloz an excellent alternative for growing in the different regions of the state of São Paulo.

Table 1. Mean grain yield of the cultivar IAC Veloz and of the controls IAC Diplomata and IAC Una in VCU trials carried out in the two-year period of 2013/2014/2015 in the three crop seasons indicated by agroecological zoning of the crop, considering only those trials with a coefficient of experimental variation lower than $25 \%$ as viable

\begin{tabular}{|c|c|c|c|c|c|c|}
\hline \multirow{2}{*}{ Location } & \multirow{2}{*}{ Crop season } & \multirow{2}{*}{$\begin{array}{l}\text { IAC Veloz } \\
\left(\mathrm{kg} \mathrm{ha}^{-1}\right)\end{array}$} & \multicolumn{2}{|c|}{ Controls (kg ha-1) } & \multirow{2}{*}{$\begin{array}{l}\text { Mean yield of the } \\
\text { controls }\end{array}$} & \multirow{2}{*}{$\begin{array}{c}\text { Coefficient of variation } \\
(\%)\end{array}$} \\
\hline & & & IAC Diplomata & IAC Una & & \\
\hline Capão Bonito & Rainy/2013 & 2991.70 & 3491.70 & 2945.80 & 3218.75 & 10.60 \\
\hline Mococa & Rainy/2013 & 2995.80 & 2554.20 & 2487.50 & 2520.85 & 9.14 \\
\hline Tatuí & Rainy/2013 & 2380.15 & 2322.15 & 2116.37 & 2219.26 & 15.60 \\
\hline Capão Bonito & Dry/2014 & 1425.40 & 1537.50 & 1408.30 & 1472.90 & 20.00 \\
\hline Mococa & Dry/2014 & 2862.50 & 2995.80 & 2995.80 & 2995.80 & 13.89 \\
\hline Votuporanga & Winter/2014 & 2712.50 & 3220,83 & 2975.00 & 2975.00 & 12.62 \\
\hline Colina & Winter/2014 & 2700.20 & 2680.58 & 2705.86 & 2693.22 & 22.35 \\
\hline Itararé & Rainy/2014 & 1758.33 & 1600.00 & 1583.33 & 1591.67 & 21.86 \\
\hline Capão Bonito & Rainy/2014 & 3770.83 & 2762.50 & 3283.33 & 3022.92 & 14.03 \\
\hline Mococa & Rainy/2014 & 2450.00 & 2350.00 & 2391.67 & 2370.84 & 17.20 \\
\hline Votuporanga & Winter/2015 & 4841.70 & 5541.70 & 4854.20 & 5197.95 & 23.88 \\
\hline Riberião Preto & Winter/2015 & 2400.00 & 1720.80 & 2204.20 & 1962.50 & 19.10 \\
\hline Colina & Winter/2015 & 2610.20 & 2330.25 & 2450.38 & 2390.32 & 12.74 \\
\hline
\end{tabular}

Table 2. Mean grain yield ( $\left.\mathrm{kg} \mathrm{ha}^{-1}\right)$, experimental coefficient of variation (CV\%), and least significant difference (LSD, Dunnett - $\mathrm{p}<0.05$ ) in relation to the best standard cultivar for growing in the three common bean crop seasons, as well as in relation to the overall mean of the trait in 18 environments of the state of São Paulo that were part of the VCU trials for the two-year period of 2013/2014/2015

\begin{tabular}{|c|c|c|c|c|}
\hline \multirow[b]{2}{*}{ Common bean cultivars } & \multicolumn{3}{|c|}{ Crop season } & \multirow{2}{*}{$\begin{array}{c}\text { Mean }(2013 / 2014 / 2015) \\
\left(\mathrm{kg} \mathrm{ha}^{-1}\right)\end{array}$} \\
\hline & $\begin{array}{c}\text { Rainy } \\
\text { (6 environments) }\end{array}$ & $\begin{array}{c}\text { Dry } \\
\text { (6 environments) }\end{array}$ & $\begin{array}{c}\text { Winter } \\
\text { (6 environments) }\end{array}$ & \\
\hline IAC Veloz & 2724.47 & 2012.79 & 3035.78 & 2591.01 \\
\hline IAC Diplomata & 2513.43 & 1965.99 & 3050.69 & 2510.04 \\
\hline IAC Una & 2468.00 & 1991.04 & 2966.67 & 2475.23 \\
\hline CV (\%) & 16.70 & 14.21 & 18.90 & 21.33 \\
\hline LSD (kg ha-1) & 380 & 450 & 426 & 419 \\
\hline
\end{tabular}


Table 3. Mean response for cooking time and crude protein content by the Dunnett test $(p<0.05)$, evaluated in 18 environments in the state of São Paulo

\begin{tabular}{|c|c|c|c|c|c|c|}
\hline \multirow{2}{*}{ Crop season } & \multicolumn{2}{|c|}{ IAC Veloz } & \multicolumn{2}{|c|}{ IAC Diplomata } & \multicolumn{2}{|c|}{ IAC Una } \\
\hline & Cooking time (min) & Protein content (\%) & Cooking time (min) & Protein content (\%) & Cooking time (min) & Protein content (\%) \\
\hline Rainy & 37.77 & 20.50 & 33.12 & 21.50 & 32.74 & 20.50 \\
\hline Dry & 30.85 & 50.50 & 29.38 & 21.00 & 31.93 & 21.00 \\
\hline Winter & 27.43 & 20.50 & 27.27 & 22.00 & 29.51 & 20.00 \\
\hline Mean & 32.02 & 20.50 & 29.92 & 21.50 & 31.39 & 20.50 \\
\hline
\end{tabular}

\section{OTHER TRAITS}

The cultivar IAC Veloz exhibited cooking time statistically equivalent to the controls when evaluated by the Mattson Cooker (Proctor and Watts 1987). Crude protein content evaluated by the micro Kjeldahl method (AOAC 1980, Bataglia et al. 1983) for the IAC Veloz cultivar had an overall mean performance similar to that of IAC Una, which was lower than IAC Diplomata, but was not significantly lower than the mean values exhibited by the controls (Table 3).

The IAC Veloz cultivar has a determined growth habit, upright plant type, 1000 seed weight of 220 grams, and 75day cycle from emergence to physiological maturity. It is thus considered to be of early maturity, and its upright plant type facilitates mechanical grain harvest. Due to the early maturity and shorter exposure time in the crop field from sowing to harvest contributed this genotype had a intermediate performance when exposed to water deficit and to low temperature, as well as to high temperature in the reproductive phase. It exhibits resistance to the diseases of anthracnose, rust, and common mosaic, and moderate resistance to bacterial blight, angular leaf spot, Fusarium wilt, and bacterial wilt.

\section{TECHNICAL RECOMMENDATION AND SEED PRODUCTION}

Due to the early cycle, upright plant type, grain yield, and tolerance to the pathogens of Anthracnose and Fusarium oxysporum shown by the IAC Veloz cultivar, it is recommended for growing in the rainy, dry, and winter crop seasons in the state of São Paulo, and may also be recommended for the rainy and dry crop seasons in the states of Paraná, Santa Catarina, Rio Grande do Sul, and Mato Grosso do Sul.

To correctly manage the crop and achieve the yield potential of the cultivar, we recommend between-row spacing of $50 \mathrm{~cm}$ and density of 12 plants per meter, resulting in a population of 240.000 plants per hectare. Other factors that may also affect the grain yield of the cultivar IAC Veloz are the crop season (rainy, dry, or winter), the growing region, and the technological level of production.

\section{REFERENCES}

AOAC (1980) Official methods of analysis of the A.O.A.C. Association of Official Analytical Chemists, US Government Printing Office, Washington D.C, $15 p$.

Barili LD, Vale NM, Carneiro JES, Silva FF and Silva FL (2016) Five decades of black common bean genetic breeding in Brazil. Pesquisa Agropecuária Tropical 46: 259-266.

Bataglia OC, Furlani AMC, Teixeira JPF, Furlani PR and Gallo JR (1983) Métodos de análise química de plantas. Instituto Agronômico, Campinas, 48p. (Boletim Técnico, 78).

Carbonell SAM, Chiorato AF, Bolonhezi D, Barros VLNP, Borges WLB, Ticelli M, Gallo PB, Finoto EL and Santos NCB (2014) IAC Milênio - Common bean cultivar with high grain quality. Crop Breeding and Applied Biotechnology 14: 273-276.

Carbonell SAM, Chiorato AF, Gonçalves JGR, Perina EF and Carvalho CRL
(2010) Tamanho de grão comercial em cultivares de feijoeiro. Ciência Rural 40: 2067-2073.

Carbonell SAM, Chiorato AF, Ito MF, Perina EF, Gonçalves JGR, Souza OS, Gallo PB, Ticelli M, Colombo CA and Azevedo Filho JA (2008) IAC-Alvorada and IAC-Diplomata: new common bean cultivars. Crop Breeding and Applied Biotechnology 8: 163-166.

Chiorato AF, Carbonell SAM, Carvalho CRL, Barros VLNP, Borges WLB, Ticelli M, Gallo PB, Finoto EL and Santos NCB (2012) IAC Imperador: early maturity "carioca" bean cultivar. Crop Breeding and Applied Biotechnology 12: 297-300.

Chiorato AF, Carbonell SAM, Gonçalves JGR, Silva DA, Benchimol-Reis LL, Carvalho CRL, Barros VLNP, Freitas RS, Ticelli M, Souza PS, Gallo PB and Santos NCB (2018) IAC Sintonia: new carioca common bean cultivar. Crop Breeding and Applied Biotechnology 18: 338-342.

Chiorato AF, Carbonell SAM, Vencovsky R, Fonseca Júnior NS and Pinheiro JB (2010) Genetic gain in the breeding program of common beans at 
IAC from 1989 to 2007. Crop Breeding and Applied Biotechnology 10: 329-336.

CONAB - Companhia Nacional de Abastecimento (2020) Acompanhamento da safra brasileira grãos, safra 2019/20. Available at: <http://www. conab.gov.br/>. Accessed on June 25, 2020.

Leite PHMP, Barelli MAA, Neves LG, Silva CR and Oliveira TC (2015) Genetic divergence among common bean cultivars from precocious group. Científica 43: 143-148.

Lovato F, Kowaleski J, Silva SZ and Heldt LFS (2018) Composição centesimal e conteúdo mineral de diferentes cultivares de feijão biorfortificado (Phaseolus vulgaris L.). Brazilian Journal Food Technology 21: 2-6.

Proctor JR and Watts BM (1987) Development of a modified Mattson bean cooker procedure based on sensory panel cookability evaluation. Canadian Institute of Food Science and Technology Journal. Apple Hill 20: 9-14.

Ribeiro ND, Possebon SB and Storck L (2003) Progresso genético em caracteres agronômicos no melhoramento do feijoeiro. Ciência Rural 33: 629-633. 